\title{
Revisiting egg yolk involvement in children's food allergy to egg
}

\author{
C Brossard ${ }^{1}$, F Rancé ${ }^{2}$, A Juchet ${ }^{2}$, M Drouet $^{3}$, E Paty ${ }^{4}, S$ Legoué-Morillon ${ }^{5}$, F Nau ${ }^{6}$, M Anton ${ }^{1}$, S Denery ${ }^{1 *}$ \\ From Food Allergy and Anaphylaxis Meeting (FAAM 2013) \\ Nice, France. 7-9 February 2013
}

\section{Background}

Food allergy to egg is commonly diagnosed in childhood with good prognosis. Egg white is considered as the main culprit with major 4 identified allergens (Gal d 1 to Gal d 4). Egg yolk (with two identified allergens Gal d 5 and Gal d 6 in the livetin fraction) retained less attention and its clinical involvement remains unclear. This study revisits sensitization to both egg fractions in a cohort of children allergic to egg and investigates IgE reactivity toward the main egg yolk fractions.

\section{Methods}

Children with food allergy to egg were recruited. Crude egg and crude white and yolk fractions, carefully prepared to avoid any contamination between yolk and white, were used for prick-tests in this cohort. Specific IgE in sera towards egg yolk fractions (lipovitellins/HDL, lipovitellenins/LDL, phosvitins and livetins) were determined by ELISA.

\section{Results}

Fifty-two children (13 girls; $3.9 \pm 1.7$ years old) with food allergy to egg were recruited. They mainly suffered from urticaria (48\%) and to a lesser extend from eczema (11\%), rhinitis (11\%) and gastrointestinal troubles (9\%). At inclusion, all children had positive prick-tests to crude egg and crude white fraction, $78 \%$ to crude yolk fraction. Diameters of positive prick-tests were $10.1 \pm 5.2 \mathrm{~mm}$ for crude egg; $12.7 \pm 7.2 \mathrm{~mm}$ for egg white and $8.9 \pm 5.1 \mathrm{~mm}$ for egg yolk. Among egg yolk fractions, IgE in sera interacted more frequently with lipovitellenins/LDL (30\%) and livetins (30\%) than lipovitellins/HDL (16\%) and phosvitins (4\%) fractions.

${ }^{1}$ UR1268 Biopolymères, Interactions, Assemblages, INRA, Nantes, France

Full list of author information is available at the end of the article

\section{Conclusion}

Beside sensitization to egg white, children with allergy to egg appear to be more frequently sensitized to egg yolk than generally assumed. IgE reactivity to egg yolk is more directed toward the plasma proteins in lipovitellenins/LDL and livetins fractions than the granules proteins in lipovitellins/HDL and phosvitins fractions.

\section{Disclosure of interest}

None declared.

\section{Author details}

'UR1268 Biopolymères, Interactions, Assemblages, INRA, Nantes, France. ${ }^{2}$ Pédiatrie - Pneumologie, Allergologie, CHU Toulouse, Toulouse, France. ${ }^{3}$ Pneumologie - Unité Allergologie Générale, CHU d'Angers, Angers, France. ${ }^{4}$ Pneumo Allergologie Infantile, $\mathrm{CHU}$ Necker, Paris, France. ${ }^{5}$ Centre de Recherche et d'Education en Allergie Alimentaire, CHU de Nantes, Nantes, France. ${ }^{6}$ UMR1253 Sciences et Technologie du Lait et de I'Oeuf, INRA/ AgroCampus Ouest, Rennes, France.

Published: 25 July 2013

doi:10.1186/2045-7022-3-S3-P86

Cite this article as: Brossard et al.: Revisiting egg yolk involvement in children's food allergy to egg. Clinical and Translational Allergy 2013 3(Suppl 3):P86.

Submit your next manuscript to BioMed Central and take full advantage of:

- Convenient online submission

- Thorough peer review

- No space constraints or color figure charges

- Immediate publication on acceptance

- Inclusion in PubMed, CAS, Scopus and Google Scholar

- Research which is freely available for redistribution

\section{Ciomed Central}

